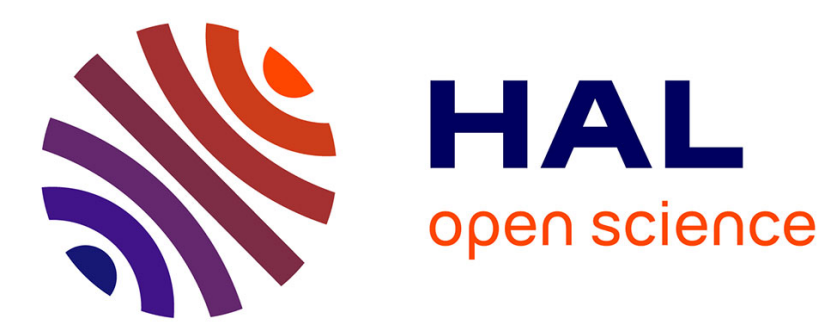

\title{
Electrophoretic pattern of peptidoglycan hydrolases, a new tool for bacterial species identification: Application to 10 Lactobacillus species
}

\author{
Sylvie S. Lortal, Florence Valence, Chantal Bizet, J.L. Maubois
}

\section{- To cite this version:}

Sylvie S. Lortal, Florence Valence, Chantal Bizet, J.L. Maubois. Electrophoretic pattern of peptidoglycan hydrolases, a new tool for bacterial species identification: Application to 10 Lactobacillus species. Research in Microbiology, 1997, 148, pp.461-474. hal-02694632

\section{HAL Id: hal-02694632 \\ https://hal.inrae.fr/hal-02694632}

Submitted on 1 Jun 2020

HAL is a multi-disciplinary open access archive for the deposit and dissemination of scientific research documents, whether they are published or not. The documents may come from teaching and research institutions in France or abroad, or from public or private research centers.
L'archive ouverte pluridisciplinaire HAL, est destinée au dépôt et à la diffusion de documents scientifiques de niveau recherche, publiés ou non, émanant des établissements d'enseignement et de recherche français ou étrangers, des laboratoires publics ou privés. 


\title{
Electrophoretic pattern of peptidoglycan hydrolases, a new tool for bacterial species identification: application to 10 Lactobacillus species
}

\author{
S. Lortal ${ }^{(1)}\left(^{*}\right)$, F. Valence ${ }^{(1)}$, C. Bizet ${ }^{(2)}$ and J.-I. Maubois ${ }^{(1)}$ \\ (1) INRA, Laboratoire de Recherches de Technologie laitière, 65, rue de Saint-Brieuc, \\ 35042 Rennes Cedex (France), and \\ (2) Institut Pasteur, Collection CIP, Paris 75724 Cedex
}

\begin{abstract}
SUMMARY
Lactobacilli have been used as industrial starters for a long time, but in many cases their phenotypic identification is still neither easy nor reliable. Previously we observed that the cell wall peptidoglycan hydrolases of Lactobacillus helveticus were highly conserved enzymes; the aim of the present work was to determine whether peptidoglycan hydrolase patterns obtained by renaturing SDS-PAGE could be of interest in the identification of lactobacilli species. For that purpose, the peptidoglycan hydrolase patterns of 94 strains of lactobacilli belonging to 10 different species were determined; most of the species studied are used either in dairy, meat, bakery or vegetable fermentations: L. helveticus, $L$. acidophilus, $L$. delbrueckii, $L$. brevis, $L$. fermentum, $L$. jensenii, $L$. plantarum, $L$. sake, $L$. curvatus and $L$. reuteri. Within a species, the strains exhibited highly similar patterns: the apparent molecular weights of the lytic bands were identical, with only slight variations of intensity. Moreover, each species, including phylogenetically close species such as $L$. sake and $L$. curvatus, or $L$. acidophilus and $L$. helveticus, gave a different pattern. Interestingly, the closer the species were phylogenetically, the more related were their patterns. The sensitivity of the method was checked using various quantities of $L$. acidophilus cells: a peptidoglycan hydrolase extract of $5 \times 10^{6}$ cells was sufficient to obtain an informative pattern, as was a single colony. Finally, the method was also successfully applied to distinguish two Carnobacterium species. In conclusion, the electrophoretic pattern of peptidoglycan hydrolases is proposed as a new tool for lactobacilli identification: it is rapid, sensitive and effective even for phylogenetically close species. Furthermore, this work provides the first evidence of the potential overall taxonomic value of bacterial peptidoglycan hydrolases.
\end{abstract}

Key-words: Autolysis, Peptidoglycan hydrolase, Lactobacillus, Carnobacterium; Identification, Renaturing SDS-PAGE.

\section{INTRODUCTION}

Over 50 species are currently recognized in the genus Lactobacillus, which is very heterogeneous.
Few of them are actually used as industrial starters in dairy, meat, fish, wine, bakery or vegetable fermentations ( $L$. helveticus, $L$. acidophilus, $L$. delbrueckii, L. paracasei, L. rhamnosus, L. plan-

Submitted February 24, 1997, accepted April 25, 1997.

$\left(^{*}\right)$ Corresponding author. 
tarum, L. brevis, L. sake, L. curvatus, etc.). Somc lactobacilli species are also recognized as valuable members of the normal flora of the mouth and the intestinal and urogenital tracts of humans and animals. The phylogenetic analysis of this genus by reverse transcriptase (RT) sequencing of $16 \mathrm{~S}$ rRNA revealed three clusters (Collins et al., 1991) which did not correspond to the three physiological groups of Bergey's manual (obligately homofermentative, facultatively heterofermentative and obligately heterofermentative). On the basis of DNA-DNA hybridization data, several changes in the taxonomy of this genus have been made, and new species have been defined (Johnson et al., 1980; Lauer et al., 1980; Weiss et al., 1983; Fujisawa et al., Dicks et al., 1996; Curk et al., 1996). In many cases, the determination of the species by biochemical assays or on the basis of growth temperature and fermentation end-products is ambiguous. For that reason, numerous identification methods at the species level have been proposed (for review see: Gasser et al., 1994; Curk et al., 1994a): for example, the electrophoretic mobilities of lactic dehydrogenases (Gasser, 1970; Uemura et al., 1994), the total soluble cell protein patterns (Dicks and Van Nuuren, 1987; Hertel et al., 1993), the analysis of cellular fatty acids and neutral monosaccharides (Rizzo et al., 1987; Decallone et al., 1991; Gilarova et al., 1994), Fourier-transform infrared spectroscopy (Curk et al., 1994b), the restriction endonuclease pattern associated with multivariate analysis (Stahl et al., 1990), M13 DNA fingerprinting (Miteva et al., 1992) and species-specific probes (Hertel et al., 1993; Schleifer et al., 1995). Each of these methods has specific applications and advantages, but most of them involve an extraction step of the DNA or require particular equipment or have been developed for a small number of species.

Peptidoglycan (PG) hydrolases are endogenous cell wall bacterial enzymes that hydrolyse bonds in the protective and shape-maintaining peptidoglycan (Shockman and Höltje, 1994). Depending on their specificity (glycosidase, amidase, peptidase), they hydrolyse various bonds in this three-dimensional network. Most often, several PG hydrolases of various specificities coexist in the cell wall. Numerous potential roles in bacterial growth and division have been proposed for these enzymes (Rogers et al., 1980) but most of them, as well as their regulation, are still not clearly established. Some of these PG hydrolases, named autolysins, are able to provoke bacterial autolysis in particular conditions and for that reason, must be well regulated. Recently, a powerful method was described to visualize lytic ensymes, including bacterial PG hydrolases, after SDS-PAGE (Audy et al, 1988; Leclerc et Asselin, 1989). In the framework of our study of the autolytic system of L. helveticus (Valence and Lortal, 1995), this method was applied to several strains. Using whole cells of Micrococcus luteus as substrate included in the gel, several PG hydrolases were detected at 42 and $30 \mathrm{kDa}$. We noticed that for all the strains the pattern was the same regarding the molecular weight of the PG hydrolases; only the intensity of the lytic bands was in some cases variable. As the strains came from various geographical origins and were not genomically closely related as shown recently by genomic DNA macrorestriction analysis (Lortal et al, 1997), this observation suggested that PG hydrolases are highly conserved enzymes and could eventually be a useful taxonomic marker for species determination.

The aim of this work was to determine whether PG hydrolase patterns can be a reliable new phenotypic tool for the identification of a large number of lactobacilli species.

\section{MATERIALS AND METHODS}

\section{Bacterial strains and growth conditions}

The origin of the lactobacilli strains is given in table I. They were stored at $-70^{\circ} \mathrm{C}$ in MRS medium (de Man et al., 1960) containing 15\% (v/v) glycerol. The cultures were performed at 30 or $37^{\circ} \mathrm{C}$ (as indi-
MRS = Man-Rogosa-Sharpe (medium).

$\mathrm{PG}=$ peptidoglycan.
SDS-

PAGE = sodium dodecyl sulphate/polyacrylamide gel electrophoresis. 
Table I. Origin of the strains.

\begin{tabular}{|c|c|c|}
\hline Strain & Source & Other strain designation(s) \\
\hline \multicolumn{3}{|l|}{ L. acidophilus $\left(37^{\circ} \mathrm{C}\right)$} \\
\hline CNRZ $204^{\mathrm{T}}$ & Human & $\begin{array}{l}\text { ATCC } 4356, \text { CIP } 76.13, \text { DSM } \\
20079, \text { LMG } 7943 / 8150, \text { NCDO } \\
1748, \text { NCIMB } 8690\end{array}$ \\
\hline CNRZ 55 & Facces, rat & NCDO 1, NCIMB 1723, ATCC 832 \\
\hline CNRZ 216 & Digestive flora, conventional rat; France & \\
\hline CNRZ $217 \bullet$ & Digestive flora, conventional rat; France & \\
\hline CNRZ 251 & Comté artisanal lactic starter; France & \\
\hline CNRZ $462 \bullet$ & Lactic starter; Germany & \\
\hline \multirow{2}{*}{\multicolumn{3}{|c|}{$\begin{array}{l}\text { CNRZ 1081• } \\
\text { CNRZ } 1295\end{array}$}} \\
\hline & & \\
\hline CIP 103595 & Human isolate & ATCC 4357, NCDO 1697, NCIMB 8607 \\
\hline CIP 103600 & Sweet acidophilus milk & \\
\hline \multicolumn{3}{|l|}{ CIP 103601} \\
\hline SC 41 & Argentina & \\
\hline \multicolumn{3}{|l|}{ L. brevis $\left(30^{\circ} \mathrm{C}\right)$} \\
\hline $\mathrm{CNRZ} 215^{\mathrm{T}}$ & Human faeces & $\begin{array}{l}\text { ATCC 14869, DSM 20054, } \\
\text { CIP 102806, LMG 7944, NCDO } 1749\end{array}$ \\
\hline CNRZ 234 & Dutch-type cheese; France & \\
\hline CNR7. 423 & Bakery starter; France & \\
\hline CNRZ 734 & France & \\
\hline \multicolumn{3}{|l|}{ L. curvatus $\left(30^{\circ} \mathrm{C}\right)$} \\
\hline LMG $9198^{\mathrm{T}}$ & Milk & $\begin{array}{l}\text { ATCC 25601, CIP 102992, DSM 20019, } \\
\text { NCDO 2739, NCIMB } 9710\end{array}$ \\
\hline
\end{tabular}

L. delbrueckii subsp. bulgaricus $\left(37^{\circ} \mathrm{C}\right)$

CIP $101027 \quad$ Bulgarian yoghurt; Bulgaria

ATCC 1 1842, NCDO 1489, NCIMB

11748, DSM 20081, CNRZ 208, LMG 6901

CIP 71.36

CNRZ 208

IL 29

IL 1207

IL 1215

IL 1220

Sugared yoghurt

IL 1221

Yoghurt lactic starter; France

Yoghurt lactic starter; France

IL 1222

Yoghurt lactic starter; France

IL 1224

Yoghurt lactic starter; France

IL 1225

Commercial lactic starter; France

IL 1227

Yoghurt lactic starter; France

IL 1232

Yoghurt lactic starter; France

CNRZ 61, NCDO 1373

CNRZ 384

CNRZ 396

CNRZ 397

CNRZ 398

CNRZ 400

CNRZ 401

CNRZ 417

CNRZ 422

L. delbrueckii subsp. delbrueckii $\left(37^{\circ} \mathrm{C}\right)$

CIP $57.8^{\mathrm{T}}$

CNRZ 231

Sour grain mash

Must; UK.

L. delbrueckii subsp. lactis $\left(37^{\circ} \mathrm{C}\right)$

CNRZ $207^{\mathrm{T}}$

Emmental cheese
ATCC 9649, NCDO 213, DSM 20074 NCDO 1744

ATCC 12315, NCDO 1438, DSM 20072, CIP 101028, LMG 7942 ATCC 7830, NCDO 302, NCIMB 8118, DSM 20355, LMG 6401 ATCC 4797, NCDO 299, NCIMB 8117. DSM 20076 
Strain Source Other strain designation (s)

CIP 57.5

ITG $^{(9)} 11$

ITG12

ITG 14

ITG 42

ITG 57

ITG 69

ITG 75

L. fermentum $\left(37^{\circ} \mathrm{C}\right)$ CNRZ 209

CNRZ 17

CNRZ 64

CNRZ 229

CNRZ 233

CNRZ 431

ATCC 9338

L. helveticus $\left(37^{\circ} \mathrm{C}\right)$ CIP103146 ${ }^{\mathrm{T}}$

BS8

CIP 57.15

CNRZ 32

CNRZ 58

CNRZ 67

CNRZ 241

CNRZ 303

CNRZ 414

CNRZ 493

CNRZ 834

CNRZ 1094

CNRZ 1102

CNRZ 1110

CP 615

CSL

ISLC5

IL 430

IL 590

IL 735

IL 1235

IL 1236

ITG 1

ITG 43

ITG 56

ITG $58 \bullet$

ITG 68

ITG 77

ITG 155

NCDO 262

NCDO 384

R. 5088

R. 5089

SL1 40
Fermented beet

Comté artisanal lactic starter;

Mouth

Saliva

Emmental; France

Bakery starter

Emmental swiss cheese

Grana cheese starter; Italy

Comté artisanal lactic starter; France

Emmental cheese lactic starter

Comté artisanal lactic starter; France

Comté artisanal lactic starter; France

Comté artisanal lactic starter; France

Cow milk koumis; Russia

Emmental cheese lactic starter; Finland

Emmental cheese; Switzerland

Emmental cheese lactic starter; Finland

Grana cheese artisanal starter; Italy

Commercial lactic starter; France

Japan

Industrial starter; Italy

Parmesan cheese; Italy

Industrial lactic starter isolate

Industrial lactic starter isolate

Industrial lactic starter isolate

Industrial lactic starter isolate

Industrial lactic starter isolate

ATCC 8000 , NCDO 270, NCIMB 7278

ATCC 14931, NCDO 1750, DSM 20052,

CIP 102980, LMG 6902

NCDO 335

ATCC 14933

CIP 53.163, DSM 20391, NCDO 215, NCIMB 8028

ATCC15009, CNZ 223, DSM 20075, LMG 6413, NCDO 2233, NCIMB 11971

ATCC12046, NCDO 1829, NCIMB 8733

ATCC 8018 , NCIMB 8025

Calf rennet

Canada (Rosell Institut)

Canada (Rosell Institut)

Beaufort cheese artisanal rennet; France 


Strain $\quad$ Source $\quad$ Other strain designation (s)

\section{L. jensenii $\left(37^{\circ} \mathrm{C}\right)$ CIP $6917^{\mathrm{T}}$}

L. plantarum $\left(30^{\circ} \mathrm{C}\right)$ LMG $6907^{\mathrm{T}}$

CNRZ 73
CNRZ 184
CNRZ 424
CNRZ 1008
CIP A159

NCFB 1988

L. reuteri $\left(37^{\circ} \mathrm{C}\right)$ DSM $20016^{\mathrm{T}}$

L. sake $\left(30^{\circ} \mathrm{C}\right)$ ATCC $15521^{\mathrm{T}}$
Vaginal discharge, human

Cabbage seasoned with vinegar

Sauerkraut

France

Bakery starter; France

Cheese

Faeces
ATCC 23272, NCDO 2589, NCIMB 11951, CIP 101887, LMG 9213

$\Lambda \mathrm{TCC} 25528, \mathrm{NCDO} 2165$, DSM

20557, LMG 6414

ATCC 14917, NCDO 1752, DSM 20174, CIP 103151, CNRZ 211, LMG 7945

ATCC 10241, NCDO 343, LMG 9208

ATCC 8014, NCDO 82, DSM 20205, LMG 1284

NCDO 2714, CIP 103139, LMG 9468

CNRZ = Centre National de Recherche Zootechnique, Jouy-en-Josas, France.

ATCC = American Type Culture Collection, Rockville, MD USA;

$\mathrm{CIP}=$ Collection des Bactéries de l'Institut Pasteur, Paris, France.

DSM = Deutche Sammlung von Microorganismen und Zelkulturen GmbH, Braunschweig, Germany.

LMG = Laboratorium Microbiology Gent Culture Collection, Rijksuniversiteit Gent, Belgium.

NCDO $=$ National Collection of Dairy Organism, Shinfield, Reading Berkshire, UK.

NCIMB = National Collection of Industrial and Marine Bacteria, Torry Research Station, Aberdeen, Scotland, UK.

IL = Institut National de Recherche Agronomique, Collection du Laboratoire de Technologie laitière, Rennes, France.

ITG = Institut Technique du Gruyère, La Roche-sur-Foron, France.

NCFB = National Collection of Food Bacteria, Shinfield, Reading, Berkshire, UK.

The sign indicates a potential misclassification of the strain as detected by the method of identification described in this work.

cated in table I) in MRS broth. The growth was monitored at $650 \mathrm{~nm}$ using a spectrophotometer (Beckman, DU 7400). The cultures of Carnobacterium piscicola 2762 and $C$. divergens 41 (kindly provided by P. Boyaval) were performed on MRS broth at $30^{\circ} \mathrm{C}$.

\section{Renaturing gel electrophoresis}

Renaturing SDS-PAGE (zymogram) was performed according to the method of Leclerc and Asselin (1989) using a "Bio-rad" mini-system under the following conditions: SDS/polyacrylamide separating gel (14 or $16 \%$ polyacrylamide as indicated on the figures, $\mathrm{pH} 8.8)$ containing $0.2 \%(\mathrm{w} / \mathrm{v})$ (freeze-dried M. luteus cells (Sigma) was used to detect the lytic activities). After electrophoresis ( $1 \mathrm{~h}$ for the $14 \%$ separating gel and $1 \mathrm{~h} 30 \mathrm{~min}$ for the $16 \%$, both at $180 \mathrm{~V}$, constant voltage at room temperature), the gels were soaked for $30 \mathrm{~min}$ in distilled water at room temperature. Then they were transferred into a $50-\mathrm{mM}$ Tris- $\mathrm{HCl}$ buffer at $\mathrm{pH} 8.0$ containing $1 \%(\mathrm{v} / \mathrm{v})$ Triton X-100 and gently shaken for $2 \mathrm{~h}$ at $37^{\circ} \mathrm{C}$ to enable renaturation of the enzymes. The lytic activities appeared as translucent bands on the opaque background. The contrast was enhanced by staining the gels in $0.1 \%(\mathrm{w} / \mathrm{v})$ methylene blue in $0.01 \%(\mathrm{w} / \mathrm{v})$ potassium hydroxide, destaining in distilled water under stirring and keeping the gels at least one night at $4^{\circ} \mathrm{C}$.

\section{Extraction of the PG hydrolases}

Eight $\mathrm{ml}$ of an exponential culture $\left(\mathrm{OD}_{650}\right.$ of about 1) were harvested by centrifugation $(10,000 \mathrm{~g}$, $15 \mathrm{~min}, 4^{\circ} \mathrm{C}$ ); the pellet was washed once in cold distilled water. If the analysis could not be performed extemporaneously, the 8 -ml culturc was kept at $4^{\circ} \mathrm{C}$ for one night or the washed cell pellets were frozen at $-20^{\circ} \mathrm{C}$. The pellet was directly suspended in $80 \mu \mathrm{l}$ of Laemmli buffer $(62.5 \mathrm{mM}$ Tris- $\mathrm{HCl} \mathrm{pH} 6.8$, contain- 
ing $10 \%$ glycerol, $2 \%$ SDS and $5 \% 2$-mercaptoethanol) (Laemmli, 1970). The suspension was gently mixed, heated for $2 \mathrm{~min}$ at $100^{\circ} \mathrm{C}$ (this heating step is facultative) and centrifuged $(10,000 \mathrm{~g}, 10 \mathrm{~min}) ; 15 \mu \mathrm{l}$ of the supernatant i.e., the whole-cell SDS extract which contains the PG hydrolases, was loaded on the gel. In some cases, the extraction can be improved by grinding the pellet with alumina powder for $3 \mathrm{~min}$ before adding the Laemmli buffer.

\section{Molecular mass determination of the PG hydrolases}

Ten $\mu \mathbf{l}$ of a prestained standard (Biorad) were loaded on each gel; it contained phosphorylase B, bovine serum albumin, ovalbumin, carbonic anhydrase, soybean trypsin inhibitor and lysozyme. Depending on the batch provided by Biorad, the molecular weights of these six prestained proteins varied slightly as follows: standard $1: 112,84,53.2$, $34.9,28.7$ and 20.5 ; standard $2: 105,82,49,33.3$, 28.6 and 19.4 ; standard $3: 104,80,46.9,33.5,28.3$ and 19.8. If necessary, the standard used was indicated on the figure. The prestained standard was still visible after staining the gels by methylene blue. In order to determine the apparent molecular mass of the lytic bands, the gels were scanned and analysed using a "Bioimage" system (Pharmacia).

\section{RESULTS}

PG hydrolase patterns of various lactobacilli: stability within a species and species specificity

The PG-hydrolase patterns were determined for all the strains indicated in table I, including the type strain of each species. The patterns of several strains of $L$. acidophilus, $L$. helveticus, $L$. plantarum and $L$. delbrueckii are presented in figure 1. An obvious similarity of the profiles was noted within species and in particular a high stability of the apparent molecular weight of the lytic band(s) (fig. 1a,c,d). The species $L$. delbrueckii was the only one showing a certain extent of variation in the number of the lytic bands detected, as figure 1b illustrates (from 3 to more that 10 lytic bands). Nevertheless, at least two bands were systematically present (lane 2 represents the profile most frequently encountered for that species), and the stability in the molecular weights of the lytic activities was also true for $L$. delbrueckii. It can also be highlighted that the lowest band (at $29 \mathrm{kDa}$ ) systematically had a diffuse aspect (like a smear, fig. 1b). Regarding the other species, L. sake, L. curvatus, $L$. reuteri, $L$. fermentum, $L$. brevis and $L$. jensenii, for all of which a smaller number of strains was analysed, the PG hydrolase patterns are presented in figure 2. For most of the strains, the analysis was performed at least twice, and the resuls were highly reproducible. In the case of $L$ plantarum and $L$. fermentum, the lytic bands had low intensity under the conditions used, but we noted that this intensity was enhanced by keeping the gel in the cold after staining (at $4^{\circ} \mathrm{C}$, one night to one week). With few exceptions which will be considered in the next paragraph, all the strains exhibited the same pattern as their respective type strain.

The characteristics of the PG hydrolase pattern (apparent molecular weight, intensity and aspect of the lytic bands) deduced from the observation of all the strains of the ten species considered are summarized in table II. It was obvious that each species had a specific pattern (figs. 1 and 2, table II). Interestingly, phylogenetically close species (Collins et al., 1991), such as $L$. acidophilus and $L$. helveticus, or $L$. sake and $L$. curvatus, or $L$. brevis and $L$. fermentum, exhibited close but distinct PG hydrolase patterns. For example, the presence of two additionnal lytic activities at 27 and $28 \mathrm{kDa}$ (as indicated in table II) allowed easy differentiation between $L$. acidophilus and $L$. helveticus. It can be highlighted that apparently, as far as the molecular weight of the lytic bands was concerned, the closer the species were phylogenetically, the closer were the patterns. To the best of our knowledge, this is the first report in the literature of the potential taxonomic value of PG hydrolases.

\section{Detection of potentially misclassified strains and confirmation by other techniques}

A small number of the 94 strains exhibited a PG hydrolase pattern different from the pattern of their type strain (they have been indicated by a sign ( ) in table 1): L. fermentum CNRZ 229, CNRZ 431, L. brevis CNRZ 734, L. helveticus 

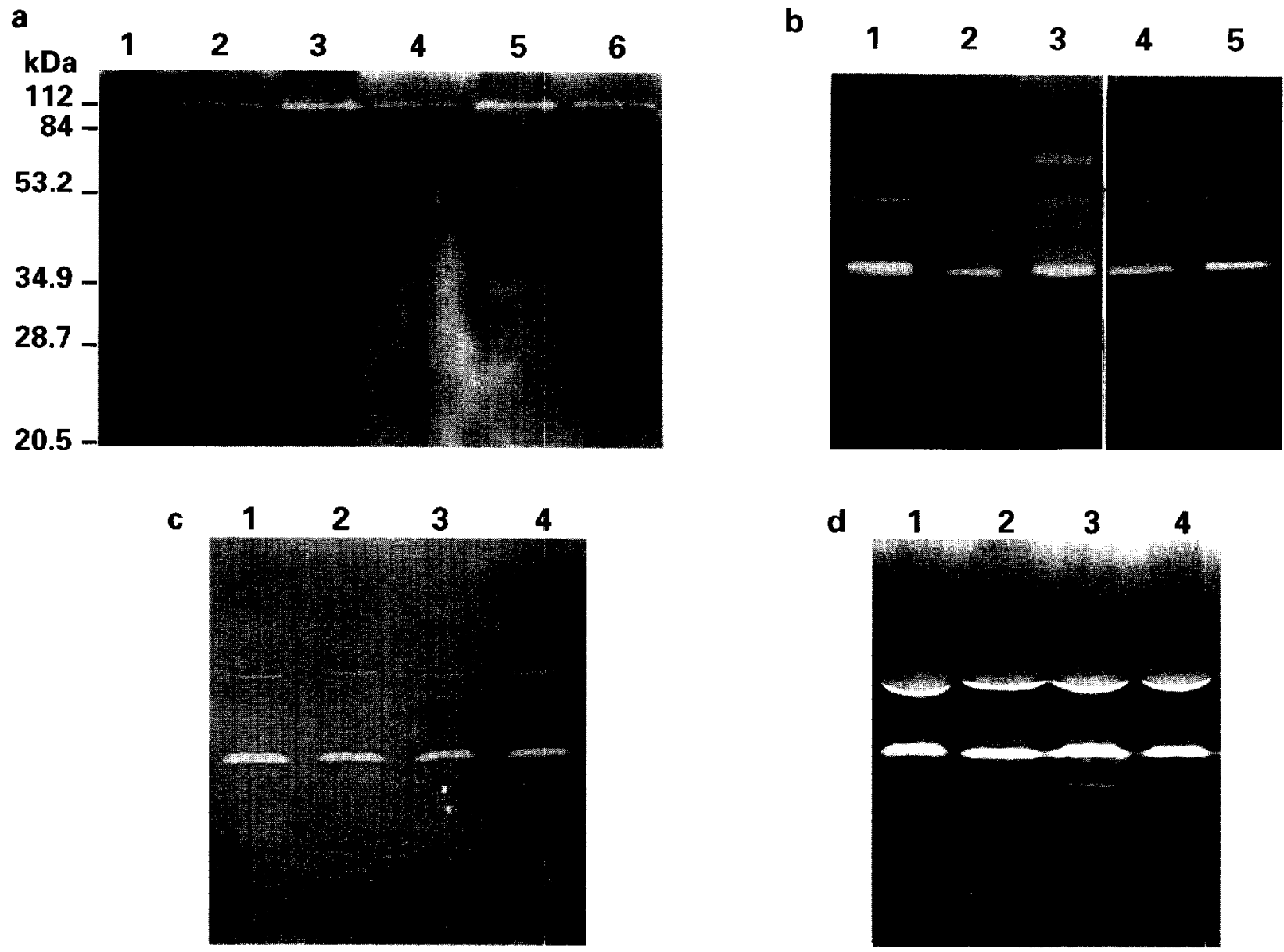

Fig. 1. PG hydrolase patterns of several strains illustrating the stability of the pattern within a species.

a) $L$. plantarum: lane $1=$ prestained standard no. 1 , lane $2=L M G 6907^{\mathrm{T}}$, lane $3=$ NCFB 1988 , lane $4=$ CNRZ 73, lane $5=$ CNRZ 184, lane $6=$ CNRZ 1008; b) L. delbrueckii: lane $1=$ IL1207, lane $2=$ IL1222, lane $3=$ IL1227, lane $4=\mathrm{IL} 1221$, lane $5=\mathrm{IL1220}$; c) $L$. helveticus: lane $1=\mathrm{IL}$ 590, lane $2=$ IL 735, lane $3=$ IL 1235, lanc $4=$ IL 1236; d) L. acidophilus: lanc $1=$ CIP 103601, lane $2=\mathrm{CIP} 103595$, lane $3=\mathrm{CIP} 103600$, lane $4=\mathrm{CNRZ} 204^{\mathrm{T}}$. The apparent masses of the lytic bands detected are given in table II.

ITG 58, L. acidophilus CNRZ 217, CNRZ 251, CNRZ 462 and CNRZ 1081. Taking into account the observations made in the previous paragraph, misclassification of these strains could be suspected. The pattern exhibited by strain ITG 58 was similar to the type strain of $L$. delbrueckii. Carbohydrate fermentation profiles (API $50 \mathrm{CH}$ strips) and electrophoretic protein profile (data not shown) indicated that this strain effectively belongs to the species $L$. delbrueckii subsp. lactis.
Regarding the strains L. fermentum CNRZ 229 and CNRZ 431 and L. brevis CNRZ 734, carbohydrate fermentation profiles (API strips) were performed. The results indicated that strain 229 , which is supposed to belong to $L$. fermentum, had a profile better matching that of $L$. brevis. Nevertheless, two sugars should not be fermented (Dmannose, D-mannitol), and the aesculin should not be hydrolysed. The sugar fermentation profile of strain 431 matched well with the species $L$. fermentum. Strain 734 showed a fermentation 
Table II. PG hydrolase patterns of the ten lactobacilli species.

\begin{tabular}{lc}
$\begin{array}{l}\text { Species }{ }^{(a)} \\
\text { L. helveticus }\end{array}$ & $\begin{array}{c}\text { Characteristics of the lytic bands } \\
(\mathrm{MW})\end{array}$ \\
\hline L. acidensity, aspect)
\end{tabular}

(a) Obtained in the conditions described in "Materials and Methods"; (b) schematized patterns; dotted lines correspond to minor lytic bands which were not considered because of excessive weakness, absence of reproducibility and/or bad resolution; ${ }^{(c)} \mathrm{MW}$ : apparent molecular weight; intensity: 1 = very weak to weak; $2=$ middle; 3 = strong; aspect : if they are typical, incurvation and/or thickness were indicated.

profile of $L$. brevis, with the exception of two sugars which should not be fermented: D-mannose and 2-ceto-D-gluconate. In order to have a clearer answer regarding these three strains, their total protein contents were analysed by SDSPAGE and compared with profiles of strains in a data bank, and their PG type was determined. The results (C. Barreau, Institut Pasteur, personal 
communication) indicatcd that at lcast two of the three strains were effectively misclassified. Strains 229 and 431 cannot be classified as L. fermentum, since their PG type was not of the OrnD-Asp type as expected for that species, but belongs to the more classical Lys-D-Asp type. Moreover, the protein profile of strain CNRZ 229 was similar to that of $L$. brevis (confirming the indication of the API strips), and the protein profile of strain 431 did not match with anything. Strain CNRZ 734 might belong to L. brevis, but its protein profile matched better with $L$. brevis CIP 103474 than with the type strain, CIP 71.35. This observation could be explained by the heterogeneity of the L. brevis group, which has already been detected (Dicks and Van Vuuren, 1987).

The $L$. acidophilus group is also highly heterogenous; because of the absence of any simple phenotypic way to distinguish the six DNA homology groups described (A1, A2, A3, A4, B1 and B2) (Johnson et al., 1980; Lauer et al., 1980), the potential misclassification of strains CNRZ 217, CNRZ 251, CNRZ 462 and CNRZ
1081 was not verified in that work. Nevertheless, the protein profiles of these four strains were analysed by SDS-PAGE (dala not shown), and it was obvious that CNRZ 462 and CNRZ 251 were devoid of the predominant S-layer-forming protein which was described as a typical feature of the group A1, A2, A3 and A4 (Johnson et al., 1987; Lortal, 1993), confirming their misclassification.

\section{Sensitivity of the method and direct use from a colony}

All the aforementioned results were obtained with less than $10 \mathrm{ml}$ of broth of an exponential culture. We determined that about $10^{8}$ cells were present in the pellet to which $80 \mu 1$ of Laemmli buffer was added; $15 \mu \mathrm{l}$ of the SDS-whole cells extract were loaded into the polyacrylamide gel. From these values, it can be assessed that a quantity of PG hydrolases extracted from $10^{7}$ cells is required to obtain a satisfying pattern (figs. 1 and 2 ). In order to verify whether it would be possible
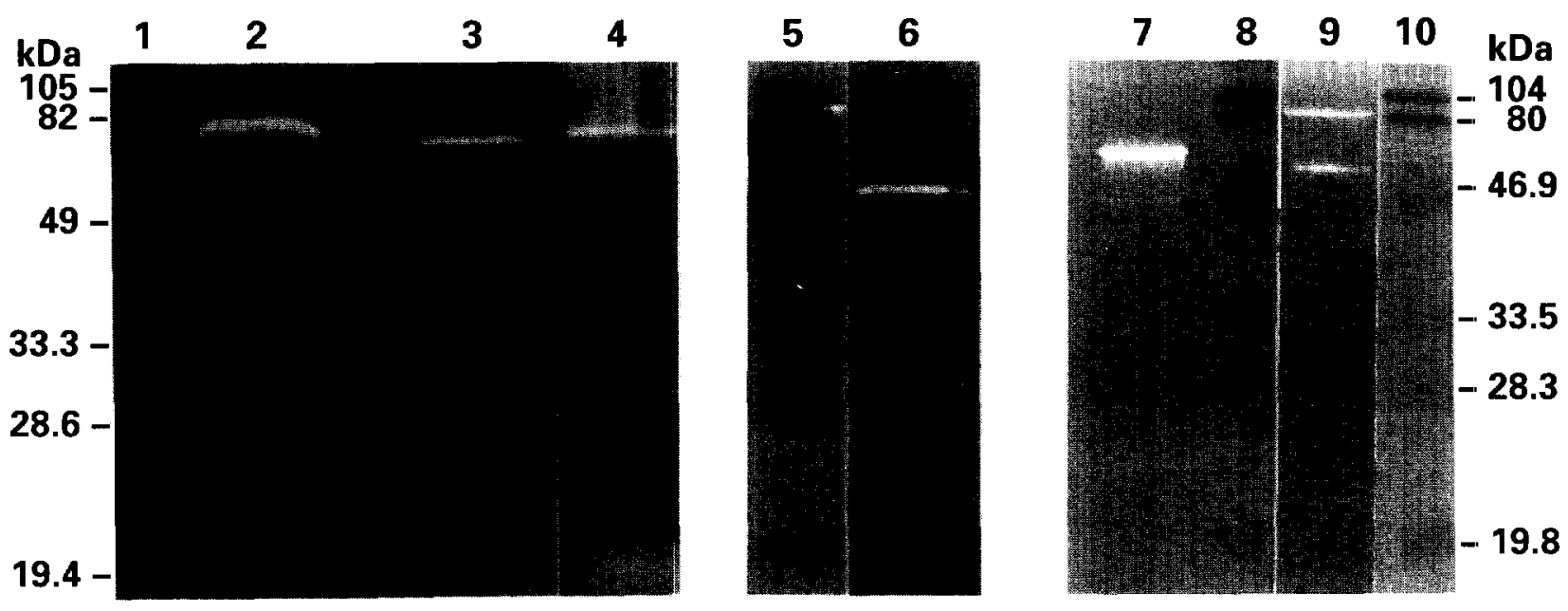

Fig. 2. PG hydrolase patterns of the six other species studied in this work, further illustrating the species specificity.

Lane $1=$ prestained standard no. 2, lane $2=L$. sake ATCC $15521^{\mathrm{T}}$, lane $3=$ L. curvatus LMG $9198^{\mathrm{T}}$, lane $4=L$. jensenii CIP $6917^{\mathrm{T}}$, lane $5=$ prestained standard no. 2 , lane $6=L$. fermentum CNRZ $209^{\mathrm{T}}$, lane $7=L$. reuteri $\mathrm{DSM} 20016^{\mathrm{T}}$, lane $8=$ prestained standard no. 3 , lane $9=L$. brevis, CNRZ $215^{\top}$, lane $10=$ prestained standard no. 3. The apparent masses of the lytic bands for all the species shown here are given in table II. 
to reduce this quantity of cells, successive dilutions of an exponential culture of $L$. acidophilus CIP103600 were performed. Each of seven pellets containing $4 \times 10^{6}$ to $4 \times 10^{9}$ cells was treated with $80 \mu \mathrm{l}$ of Laemmli buffer in order to extract the PG hydrolases. As $10 \mu l$ were loaded per lane, it can be estimated that the quantity of
PG hydrolases loaded was extracted from a number of cells ranging from $5 \times 10^{5}$ to $5 \times 10^{8}$ cells. The samples were loaded on an $M$. luteuscontaining gel and in parallel on a gel devoid of substrate in order to obtain the protein profiles of the extracts. For that species at least, the method can be applied with $5 \times 10^{6}$ cells only (fig. 3 ). It

\section{a}

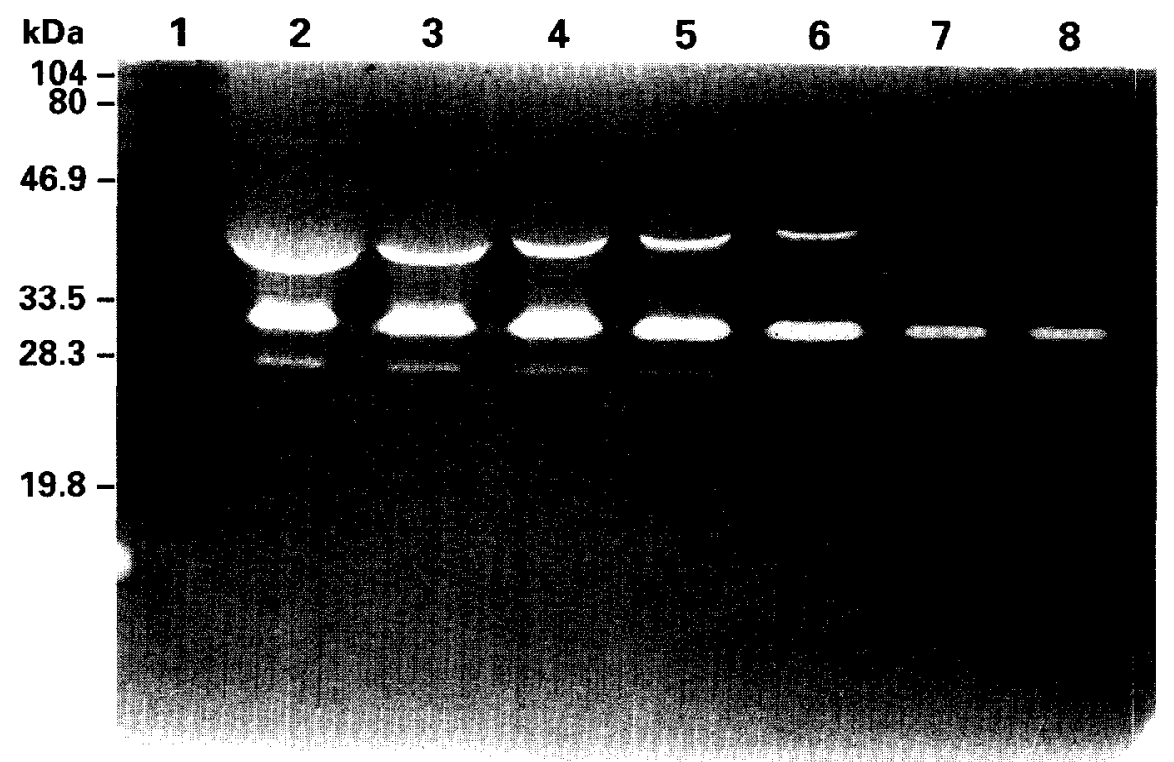

b

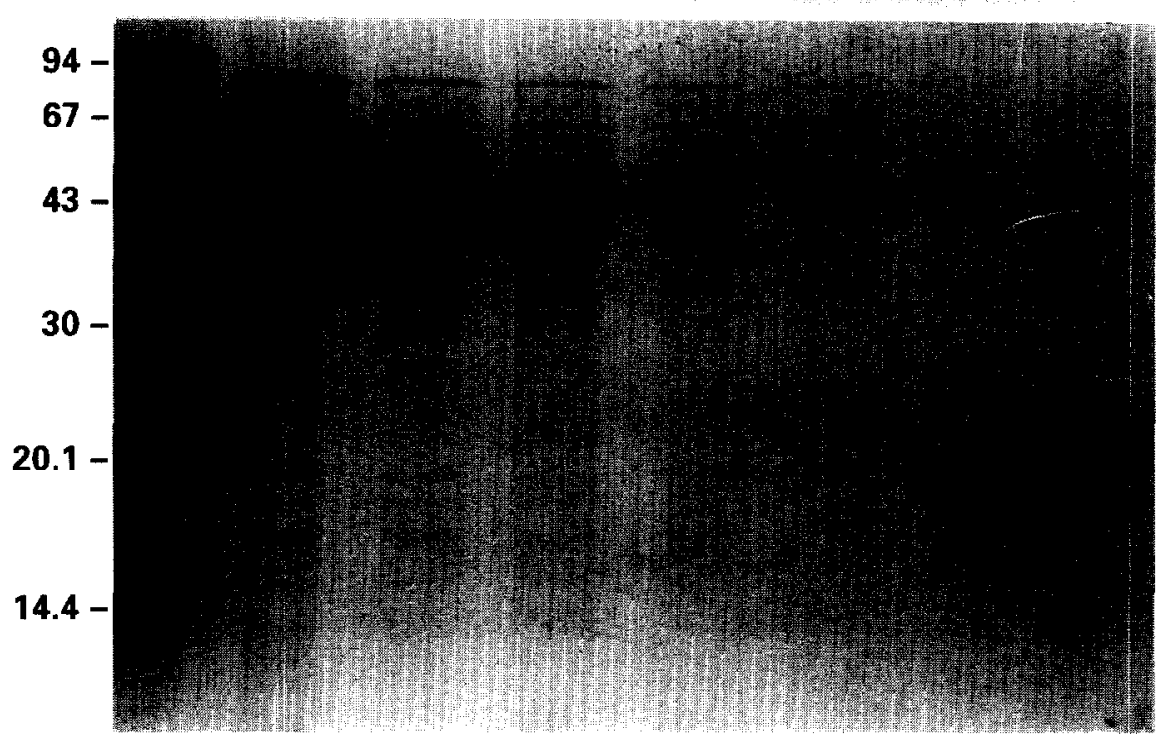

Fig. 3. Evaluation of the sensitivity of the method.

a) PG hydrolase patterns and b) SDS-PAGE patterns obtained from various quantities of L. acidophilus CIP 103600 whole cells: lane $1=$ standards, lane $2=5 \times 10^{8}$, lane $3=10^{8}$, lane $4=$ $5 \times 10^{7}$, lane $5=10^{7}$, lane $6=5 \times 10^{6}$, lane $7=10^{6}$, lane $8=5 \times 10^{5}$. 
should be underscored that within a rather large range of cells studied, the characteristics of the pattern were not modified. Nevertheless, below a certain number of cells, the intensity of the $40-$ $\mathrm{kDa}$ lytic band was significantly reduced; in a similar manner, when an excessive quantity of cells were treated, the interpretation of the pattern could be altered. Thus, it was concluded that ideally a pellet containing $5 \times 10^{6}$ to $5 \times 10^{7}$ bacterial cells should be used in order to obtain satisfactory PG hydrolase patterns. With the same objective in mind, single colonies of $L$. acidophilus and of $L$. sake with a size between 1 and $2 \mathrm{~mm}$ were sampled and directly suspended in $50 \mu 1$ of Laemmli buffer for PG hydrolase extraction. For these two species, informative patterns identical to those obtained from a liquid culture were obtained (data not shown), indicating that growth on a solid medium did not alter them. Finally, comparison of figures $3 a$ and $3 b$ illustrated the sensitivity of the PG hydrolase detection, since lytic bands (in particular at $30 \mathrm{kDa}$ ) were still obtained when the proteins in the extracts were almost not visible (when using Coomassie blue staining).

\section{Application to other Gram-positive species}

In order to assay if the method could be applied to non-lactobacilli species, it was tested for $C$. piscicola and $C$. divergens. Again, related but distinct patterns were obtained (fig. 4). Two intense lytic bands were seen with an apparent, molecular weight of 89 and $72.7 \mathrm{kDa}$ for $C$. divergens and of 92 and $76 \mathrm{kDa}$ for $C$. piscicola. When a slightly larger quantity of PG hydrolase extract was loaded (fig. 4), it was obvious that they also differed in less intense lytic bands: two minor bands of 65 and $57.6 \mathrm{kDa}$ for $C$. divergens and two minor bands of 65 and $38.5 \mathrm{kDa}$ for $C$. piscicola.

\section{DISCUSSION}

The stability of the electrophoretic PG hydrolase pattern within a species, which was noted previously for L. helveticus (Valence and Lortal,

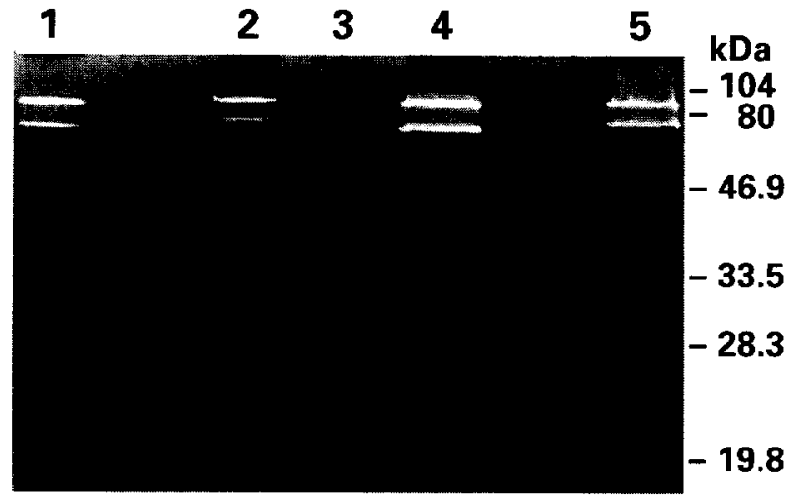

Fig. 4. Applicability of the method to other Gram ${ }^{+}$species.

PG hydrolase pattern of $C$. divergens 41 (lane $1=3 \mu \mathrm{l}$ and lane $4=15 \mu \mathrm{l}$ ) and $P G$ hydrolase pattern of $C$. piscicola 2762 (lane $2=3 \mu \mathrm{l}$ and lane $5=15 \mu \mathrm{l}$ ); lane $3=$ prestained standard no. 3 .

1995), was confirmed in this work for many other lactobacilli species. In addition, the PG hydrolase patterns of lactobacilli were shown to be speciesspecific, providing the first evidence of the taxonomic value of these enzymes or at least of their electrophoretic pattern. Indeed, the exact number of distinct PG hydrolases for a given species cannot be determined from this work; it depends on their resistance to denaturing conditions, on their ability to degrade $M$. luteus and on the eventual presence of proteolytically derived forms of the same enzyme. This last hypothesis is rather realistic, since it has been shown for $I$. lactis that the deletion of one gene (autolysin, $a c m A$ ) led to the disappearance of all the lytic activities in the pattern (Buist et al., 1995). Nevertheless, independently of the precise number of distinct enzymes, the PG hydrolase patterns obtained in standardized conditions as described here can be used as an identification tool as in our patent (Lortal et al., 1995). Indeed, in addition to the stability and specificity of the patterns, some observations presented here strongly supported the taxonomical value of the proposed method. First, the closer the species were phylogenetically, the closer were their patterns. This was particularly obvious for $L$. helveticus and $L$. acidophilus and for the group $L$. sake, L. curvatus and $L$. reuteri.Secondly, misclassification, sus- 
pected for some strains because of a PG hydrolase pattern different from that of the type strain, was effectively confirmed by other analyses.

To our mind, the total number of lytic bands as well as their apparent molecular weight constitute the objective criteria to consider in order to identify a species, but the aspect of the bands (incurvation, thickness, intensity) may also be useful to take into account. For example, $L$. reuteri and $L$. sake led to one thick and intense band compared with $L$. curvatus, which in the same molecular weight area, led to one thin intense band just above several weak lytic activities. Furthermore, the presence in some species like L. helveticus and $L$. acidophilus of an S-layer-forming protein (Lortal, 1993) just above the 40-kDa lytic activities, deformed them, causing an incurved aspect. In order to use the method as a new taxonomical tool, a bank of patterns which would take into account all the aforementioned characteristics (molecular weight and aspect of the bands) should be developed.

Compared with other identification tools developed for lactobacilli, the proposed method exhibits numerous advantages: it is easy, cheap and rapid (like protein electrophoresis), sensitive (it can be applied to a single colony) and effective, as it was able to distinguish closely related lactobacilli species. Further investigations are, however, required to see if it can be effective enough to distinguish the 6 DNA-homology clusters constituting the so-called $L$. acidophilus group (Johnson et al., 1980; Lauer et al., 1980). In addition, some limitations still exist. For example, the patterns obtained for 10 different lactobacilli species were obtained, but under the conditions used, it was easier to obtain informative patterns (intense lytic bands) for some species ( $L$. acidophilus, $L$. helveticus, $L$. sake, $L$. curvatus and $L$. reuteri) than for the others ( $L$ fermentum, $L$. plantarum, $L$. brevis, L. jensenii and $L$. delbrueckii). For these last species an optimization of the procedure has to be performed, concerning in particular the PG hydrolase extraction method and the renaturing conditions $(\mathrm{pH}$, temperature and nature of the buffer).

As PG hydrolases are supposed to be ubiquitous enzymes, this method could be used for non- lactobacilli species. In this work distinct $P G$ hydrolase patterns were effectively observed for two Carnobacterium species. Preliminary data were also obtained for dairy propionibacteria (Lortal et al., 1995), enabling the differentiation of the three phylogenetically close species Propionibacterium thoenii, $P$. acidipropionici and $P$. jensenii, but the conditions used were different from those described in the present work. PG hydrolase patterns of numerous $\mathrm{Gram}^{+}$and Gram $^{-}$species have been described in the literature (Foster, 1992; Bernadsky et al., 1994). Unfortunately, most often only one strain per species was described, and thus the stability within a species cannot be assessed and a fortiori, the species specificity. Nevertheless, it was observed that the PG hydrolase patterns of several L. lactis strains were highly similar (Chapot-Chartier, 1996; Buist et al., 1995), and 10 different clinical strains of Staphylococcus aureus also gave identical patterns (Sugai et al., 1990). These two examples, at least, supported the hypothesis that the pattern stability between strains of a same species is a general property. In conclusion, from the survey of the literature as well as from the data of this study, the electrophoretic PG hydrolase pattern can constitute a new phenotypic tool in bacterial identification.

\section{Acknowledgements}

The authors are sincerely indebted to C. Barreau for the identification by SDS-PAGE analysis and PG type determination as well as to $P$. Tailliez for providing us with most of the CNRZ strains. Wc thank also M.C Montel and E. Neviani for giving us some of their strains.

\section{Profil électrophorétique des hydrolases du peptidoglycane, une nouvelle méthode d'identification des espèces bactériennes: application à 10 espèces de lactobacilles}

Les lactobaciles sont utilisés depuis longtemps dans de nombreuses fermentations, mais leur identification phénotypique est parfois encore difficile ou imprécise. Dans un précédent article, nous avions observé que les hydrolases du peptidoglycane de Lactobacillus helveticus étaient des enzymes haute- 
ment conservées. Le but du présent travail est de déterminer si les profils électrophorétiques des hydrolases de peptidoglycane, obtenus après électrophorèse renaturante, selon Leclerc et Asselin, peuvent constituer un nouvel outil d'identification. Le profil des hydrolases de peptidoglycane a été déterminé pour 94 souches de lactobacilles appartenant à 10 espèces différentes; la plupart de ces espèces sont utilisées industriellement dans divers procédés fermentaires (laitiers ou non): $L$. helveticus, $L$. acidophilus, L. delbrueckii, L. brevis, L. fermentum, $L$. jensenii, $L$. plantarum, $L$. sake, $L$. curvatus et $L$. reuteri. Les souches d'une même espèce présentent un profil hautement similaire: le poids moléculaire apparent des activités lytiques est identique et seule leur intensité varie légèrement. De plus, il est apparu que chaque espèce présente un profil différent. Des espèces très proches telles que $L$. sake et $L$. reuteri ou encore $L$. helveticus et $L$ acidophilus peuvent être aisément différenciées. Il est à noter que plus les espèces sont proches phylogénétiquement, plus leur profils sont semblables. La sensibilité de la méthode a été testée par l'extraction des hydrolases de peptidoglycane à partir de quantités croissantes de cellules de $L$. acidophilus, et $5 \times 10^{6}$ cellules (ainsi qu'une colonie de $2 \mathrm{~mm}$ de diamètre) se sont avérées suffisantes pour obtenir un profil satisfaisant. Enfin, la méthode a également été appliquée avec succès pour la différenciation de deux espèces de Carnobacterium. En conclusion, le profil électrophorétique des hydrolases du peptidoglycane est proposé comme une nouvelle méthode d'identification des lactobacilles: c'est une méthode sensible, rapide et efficace, même pour des espèces proches. De plus, ce travail représente la première mise en évidence de l'intérêt taxonomique des hydrolases du peptidoglycane.

Mots-clés: Autolyse, Peptidoglycane hydrolase, Lactobacillus, Carnobacterium; Identification, Electrophorèse renaturante.

\section{References}

Audy, P., Grenier, J. \& Asselin, A. (1989), Lysozyme activity in animal extracts after sodium dodecyl sulfate-polyacrylamide gel electrophoresis. Comp. Biochem. Physiol., 92B, 523-527.

Bernadsky, G., Beveridge, T.J. \& Clarke, A. (1994), Analysis of the sodium dodecylsulfate stable peptidoglycan autolysins of select gram-negative pathogens by using renaturing gel electrophoresis. J. Bacteriol., 176,5225-5232.

Buist, G., Kok, J., Leenhouts, K.J., Dabrowska, M., Venema, G. \& Haandrikman, A.J. (1995), Molecular cloning and nucleotide sequence of the gene encoding the major peptidoglycan hydrolase of Lactococ- cus lactis, a muramidase needed for cell separation. J. Bacteriol., 177, 1554-1563.

Chapot-Chartier M.P. (1996), Les autolysines de bactéries lactiques. Lait, 76, 91-109.

Collins, M.D., Rodrigues, U., Ash, C., Aguirre, M., Farrow, J.A.E., Martinez-Murcia, A., Phillipps, B.A., Williams, A.M. \& Wallbanks, S. (1991), Phylogenetic analysis of the genus Lactobacillus and related lactic acid bacteria as determined by reverse transcriptase sequencing of 16S rRNA. FEMS Microbiol. Lett., 77, 5-12.

Curk, M.C., Peladann F. \& Hubert J.C. (1994a), Identification bactérienne par spectrometrie infrarouge à Transformée de Fourier. Bull. Soc. Fr. Microbiol., 9, $278-283$

Curk, M.C., Bcufgras, J.M., Decaris, B., Gavini, F., Kersters, K., Larpent, J.P., Le Bourgeois, P., Renault, P., de Roissart, H. \& Fouvier C. (1994b), Méthodes d'identification des bactéries lactiques, in "Bactéries lactiques, vol 1" (H. de Roissard and F.M. ILuquet, eds.). Lorica, France.

Curk, M.C., Hubert, J.C. \& Bringel F. (1996), Lactobacillus paraplantarum sp. nov., a new species related to Lactobacillus plantarum. Int. J. System. Bacteriol., 46, 595-598.

Decallonne, J., Delmée, M., Wautho7, P., Fl Lioui, M. \& Lambert, R. (1991), A rapid procedure for the identification of lactic acid bacteria based on the gas chromatographic analysis of the cellular fatty acids. J. Food Prot., 54, 217-224

De Man, J.C., Rogosa, M. \& Sharpe, E. (1960), A medium for the cultivation of the lactobacilli. J. Appl. Bacteriol., 23, 130-135.

Dicks, L.M.T. \& Van Vuuren, H.J.J. (1987), Relatedness of heterofermentative Lactobacillus species revealed by numerical analysis of total soluble cell protein patterns. Int. J. System. Bacteriol., 4, 437-440.

Dicks, L.M.T., du Plessis, E.M., Dellaglio, F. \& Lauer, E. (1996), Reclassification of Lactobacillus casei subsp. casei ATCC 393 and Lactobacillus rhamnosus ATCC 15820 as Lactobacillus zeae nom. rev., Designation of ATCC 334 as the neotype of $L$ casei subsp. casei, and rejection of the name Lactobacillus paracasei. Int. J. System Bacteriol., 46, 337-340.

Fujisawa, T., Benno, Y., Yaeshima, T. \& Mitsuoka, T. (1992), Taxonomic study of the Lactobacillus acidophilus group, with recognition of Lactobacillus gallinarum sp. nov. and Lactobacillus johnsonii sp. nov. and synonymy of Lactobacillus acidophilus group A3 (Johnson et al., 1980) with the type strain of Lactobacillus amylovorus (Nakamura, 1981). Int. J. System. Bacteriol., 42, 487-491.

Foster, S.J. (1992), Analysis of the autolysins of Bacillus subtilis 168 during vegetative growth and differentiation by using renaturing polyacrylamide gel electrophoresis. J. Bacteriol., 174, 464-470.

Gasser, F. (1970), Electrophoretic characterization of lactic dehydrogenases in the genus Lactobacillus. J. Gen. Microbiol., 62, 223-239.

Gasser, F., Montel, M.C., Talon R. \& Champomier, M. (1994), Taxonomie moléculaire appliquée à la classification des bactéries lactiques, in "Bactéries lactiques, vol. 1" (H. de Roissard and F.M. Luquet, eds.) Lorica, France.

Gilarova, R., Voldrich, M., Demnerová, K., Cerovsky, M. 
\& Dpoiás, J. (1994), Cellular fatty acids analysis in the identification of lactic acid bacteria. Int. J. Food Microbiol., 24, 315-319.

Hertel, C., Ludwig, W., Obst, M., Vogel, R.F., Hammes, W.P. \& Schleifer, K.H. (1991), 23S rNA-targeted oligonucleotide probes for the rapid identification of meat lactobacilli. System. Appl. Microbiol., 14, 173177.

Hertel, C., Ludwig, W., Pot, B., Kersters, K. \& Schleifer, K.H. (1993), Differentiation of lactobacilli occurring in fermented milk products by using oligonucleotide probes and electrophoretic protein profiles. System. Appl. Microbiol., 16, 463-467.

Johnson, J.L., Phelps, C.F., Cummins, C.F., London, J. \& Gasser, F. (1980), Taxonomy of the Lactobacillus acidophilus group. Int. J. System. Bacteriol., 30, 53-68.

Johnson, J.L., Ray, B. \& Bhowmik, T. (1987), Selection of Lactobacillus acidophilus strains for use in «acidophilus products». Antonie van Leeuwenhoek, 53, 215-231.

Laemmli, U.K. (1970), Cleavage of structural proteins during the assembly of the head of bacteriophage T4. Nature (Lond.), 227, 680-685.

Lauer, E., Helming, C. \& Kandler, O. (1980), Heterogeneity of the species Lactobacillus acidophilus (Moro) Hansen and Mocquot as revealed by biochemical characteristics and DNA-DNA hybridization. Ztbl. Bakteriol. Mikrobiol. Hyg. Abt. I Orig. C, 1, 150-168.

Leclerc, D. \& Asselin, A. (1989), Detection of bacterial cell wall hydrolases after denaturing polyacrylamide gel electrophoresis. Can. J. Microbiol., 35, 749-753.

Lortal, S. (1993), Crystalline surface-layers of the genus Lactobacillus, in "Advances in bacterial paracrystalline surface layers" (T.J. Beveridge and S.F. Koval, eds.). Plenum Press, New York.

Lortal S., Valence F., \& Maubois, J.L. (1995), Procédé d'identification d'espèces bactériennes. Demande de brevet FR 9514400.

Lortal, S., Rouault, A., Guezenec, S. \& Gauticr, M. (1997), Lactobacillus helveticus: strain typing and genome size estimation by pulsed field gel electrophoresis. Curr. Microbiol. (in press).

Miteva, V.I., Abadjeva, A.N. \& Stefanova, Tz. T. (1992), M13 DNA fingerprinting, a new tool for classifica tion and identification of Lactobacillus spp. J. Appl. Bacteriol., 73, 349-354.

Rizzo, A., Korkeala, H. \& Monomen, I. (1987), Gas chromatography analysis of cellular fatty acids and neutral monosaccharides in the identification of lactobacilli. Appl. Environ. Microbiol., 12, 2883-2888.

Rodtong, S. \& Tannock, GW. (1993), Differentiation of Lactobacillus strains by ribotyping. Appl. Environ. Microbiol., 10, 3480-3484.

Rogers, H.J., Perkins, H.R. \& Ward, J.B. (1980), The bacterial autolysins, in "Microbial cell walls and membranes". Chapman and Hall, London.

Schleifer, K.H., Ehrmann, M., Beimfohr, C., Brockmann, E., Ludwig, W. \& Amann, R. (1995), Application of molecular methods for the classification and identification of lactic acid bacteria. Int. Dairy J., 5, 10811094.

Shockman, G.D. \& Höltje, J.V. (1994), Microbial peptidoglycan (murein) hydrolases. Comprehensive biochemistry, in "Bacterial cell wall" (J.M. Ghuysen and R. Hakenbeck, eds.). Elsevier, I ondon.

Stahl, M., Molin, G., Persson, A., Ahrné, S. \& Stahl, S. (1990), Restriction endonuclease patterns and multivariate analysis as a classification tool for Lactobacillus spp. Int. J. System. Bacteriol., 2, 189-193.

Sugai, M., Akiyama, T., Komatsuzawa, H., Miyake, Y. \& Suginaka, H. (1990), Charracterization of sodium dodecyl sulfate-stable Staphylococcus aureus bacteriolytic enzymes by polyacrylarnide gel electrophoresis. J. Bacteriol., 172, 6494-6498.

Uemura, J., Toba, T., Fujisawa, T. \& Itoh, T. (1994), Identification of species among the Lactobacillus acidophilus group by electrophoresis of lactate deshydrogenase Anim. Sci. Technol., 65, 112-119.

Valence, F. \& Lortal, S. (1995), Zymogram and preliminary characterization of Lactobacillus helveticus autolysins. Appl. Environ. Microbiol., 61, 3391-3399.

Weiss, N., Schillinger, U. \& Kandler, O. (1983), Lactobacillus lactis, Lactobacillus leichmannii and Lactobacillus bulgaricus, subjective synonyms of Lactobacillus delbrueckii, and description of Lactobacillus delbrueckii subsp. lactis comb. nov. and Lactobacillus delbrueckii subsp. bulgaricus comb. nov. System. Appl. Microbiol., 4, 552-557. 